\title{
INTEGRASI REGIONAL: ARUS INVESTASI DAN IMPLIKASINYA TERHADAP PENERIMAAN PAJAK
}

\author{
Muhammad Temmy Putra Fachrezzy ${ }^{1)}$; Ferry Irawan ${ }^{2)}$ \\ 1) muh.fachrezzy@gmail.com, Direktorat Jenderal Pajak \\ 2) ferry.irawan@pknstan.ac.id, Politeknik Keuangan Negara STAN \\ * untuk penulis korespondensi
}

\begin{abstract}
The ASEAN Economic Community (AEC) has been established for several decades. The AEC is inspired by other regional communities. The situation strengthens each country' economic and investment. Based on ASEAN Statistical Yearbook 2020, in 2019 the capital inflow to ASEAN amounted USD 158 Billion. The objective of this study is to investigate the cause and effect of these global phenomenon to ASEAN countries especially Indonesia. Also, this paper will elaborate FDI effect from the tax revenue point of view. This paper uses a qualitative method in order to obtain a deep understanding. We found several findings. First, there is a relation between the establishment of regional community and foreign direct investment (FDI). Second, FDI is beneficial to enhance the tax administration system especially country's tax revenue.
\end{abstract}

Keywords: ASEAN Economic Community (AEC), Foreign Direct Investment, Tax Revenue

\begin{abstract}
Abstrak
Komunitas Ekonomi ASEAN (AEC) telah terbentuk beberapa dekade yang lalu. Pembentukan AEC dipengaruhi oleh komunitas regional lain seperti di Amerika, Afrika dan lainnya. Sesuai dengan data yang tercantum dalam laporan ASEAN 2020, pada tahun 2019 jumlah arus Foreign Direct Investment (FDI) masuk sebesar USD 159 Miliar. Tujuan dari penelitian ini adalah untuk melihat penyebab dan dampak dari fenomena global di negara anggota ASEAN khususnya Indonesia. Selain itu, artikel ini juga akan mengelaborasi pengaruh FDI dari perspektif penerimaan pajak. Penelitian ini menggunakan metode kualitatif untuk mendapatkan pemahaman yang lebih mendalam. Hasil penelitian mengindikasikan bahwa terdapat hubungan erat antara pembentukan komunitas regional dengan peningkatan FDI. Kedua, FDI bermanfaat untuk meningkatkan system administrasi pajak khususnya berkenaan dengan penerimaan pajak.
\end{abstract}

Kata Kunci : Komunitas Ekonomi ASEAN (AEC), Investasi asing langsung, penerimaan pajak

\section{PENDAHULUAN}

Globalisasi menjadi definisi yang paling sering digunakan orang untuk mendeskripsikan fenomena yang terjadi sejak akhir abad ke-20 mengenai tingkatan baru dalam interaksi antar negara, ekonomi, dan manusia di dalamnya. Globalisasi adalah proses integrasi global yang mengarahkan integrasi ekonomi melalui perdagangan, arus investasi dan modal; interaksi politik; informasi dan teknologi informasi; dan budaya (Panayotou, 2000). Ekonomi yang terglobalisasi tersebut merupakan salah satu faktor yang paling berpengaruh dalam membentuk interaksi baru pada berbagai spektrum ekonomi masyarakat.

Integrasi regional dinilai sebagai cara untuk meningkatkan peluang sebuah negara untuk memikat arus investasi. Integrasi regional mempengaruhi beberapa faktor yang menjadi determinan arus investasi seperti ukuran pasar, petumbuhan ekonomi, dan biaya perdagangan sebagaimana telah dibahas di atas. Penelitian terbaru menemukan bahwa integrasi regional tidak hanya memberikan stimulan penting bagi perdagangan, namun juga terhadap arus investasi (Brenton, Di Mauro, \& Lücke, 1999).

Arus masuk investasi asing langsung atau Foreign Direct Investment (yang selanjutnya disebut FDI) Inflows ke kawasan ASEAN mulai tumbuh pada akhir 1980an hingga awal 1990an dan meroket pada 1993 ketika bersamaan dengan dibentuknya ASEAN Free Trade Agreement (yang selanjutnya disingkat AFTA), lalu memuncak pada tahun 1997 mencapai sekitar USD 30 miliar (World Development Indicators, 2004) hingga akhirnya kembali turun saat terjadi krisis ekonomi di kawasan Association of South East Asian Nations (yang selanjutnya disingkat 


\section{JURNALKU}

Volume 1 No. 2, Juni 2021

ASEAN) pada 1997/1998. Pada Tahun 2019, FDI masuk ke ASEAN telah mencapai sekitar 158 miliar dolar AS (ASEAN Year Book, 2020) atau naik 300\% dari 1997. Dengan cepatnya pertumbuhan arus masuk FDI ke kawasan ASEAN, sangat menarik untuk membahas peran ASEAN sebagai Organisasi Integrasi Regional (yang selanjutnya disingkat OIR) meningkatkan pertumbuhan FDI dan pengaruh pertumbuhan tersebut terhadap pertumbuhan ekonomi di Indonesia.

Arah kebijakan komunitas global yang akhir-akhir ini marak membentuk atau memperkuat aliansi regional menjadi motivasi penulis untuk membahasnya. Ditambah lagi dengan keikutsertaan Indonesia di AEC, di mana Indonesia berpeluang menjadi pemain besar dalam politik internasional ASEAN. Penulis ingin melihat sebab dan akibat fenomena ini, serta implikasinya pada penerimaan pajak di negara-negara yang tergabung organisasi regional, khusunya dalam hal ini Indonesia.

Tujuan penelitian ini dapat diuraikan sebagai berikut. Pertama, untuk memeroleh pemahaman mengenai fenomena global yang sedang terjadi. Kedua, untuk mengidentifikasi berbagai bentuk integrasi regional yang terjadi di komunitas global. Ketiga, mengidentifikasi faktor-faktor yang menjadi keputusan investasi asing langsung (foreign direct investment), Keempat, merumuskan implikasi dari arus investasi yang disebabkan oleh integrasi regional ASEAN terhadap penerimaan pajak di Indonesia.

\section{KAJIAN PUSTAKA}

Teori integrasi regional telah banyak berkembang untuk menjelaskan pelbagai integrasi di seluruh dunia. Haas (1958) dalam penelitiannya membuat teori tentang integrasi regional berdasarkan pengalaman pada awal terbentuknya Uni Eropa. Teorinya tersebut pada umunya dipengaruhi oleh konsep spillover. Tiga jenis spillover telah diidentifikasikan (TranholmMikkelsen, 1991): fungsional, politis, dan cultivated. Spillover fungsional adalah ketika tujuan awal hanya dapat dicapai dengan mengambil langkah lebih lanjut dalam integrasi (Lindberg, 1963). Menurut Haas (1958), berbagai sektor dan isu sangat sulit untuk diisolasi dari pemerintah dan ekonomi, sehingga menimbulkan ketergantungan. Tekanan fungsional mencakup pelbagai ketergantungan, seperti isu-isu yang terjadi yang selalu berhubungan dengan kebijakan, politik, dan pemerintahan, juga menyebabkan pembuat kebijakan mengambil langkah tambahan dalam rangka mencapai tujuan awal integrasi spillover politis merumuskan bahwa elit politik tidak memandang suatu masalah penting dalam lingkup domestik. Konsekuensi dari hal tersebut ialah, elit politik akan terdorong untuk memromosikan integrasi, sehingga terdapat stimulus politik (Haas, 1958). Hal ini dipandang Lindberg (1963), menyebabkan peran elit politik dan proses sosialisasi yang lebih signifikan, sehingga cenderung untuk mendorong tatanan konsensus di antara negara anggota, yang pada akhirnya menghasilkan outcome yang lebih integratif.

Cultivated spillover mempersoalkan tentang peran institusi supranasional yang memperluas kekuasaannya, menjadi agen integrasi, karena dimungkinkannya mereka memperoleh keuntungan dari progress proses integrasi itu sendiri. Institusi supranasional dapat mendorong proses integrasi dengan berbagai cara, seperti bertindak sebagai policy entrepreneur (Hass, 1964). Kurangnya catatan substansial atas dinamika integrasi dijembatani oleh ilmuan neofungsionalis seperti Haas (1958) dan Lindberg (1963). Pada dasarnya, neofungsionalis berasumsi: (1) integrasi adalah sebuah proses, oleh karenanya integrasi itu sendiri butuh waktu dan bergerak sesuai dengan dinamisnya sendiri; (2) integrasi regional terbentuk oleh faktor yang banyak, beragam, dan terus berubah, khusunya badan supranasional, yang membentuk koalisi antar pemerintah dan birokrasi; (3) keputusan diambil oleh pihak yang rational, bedasarkan kepentingan sendiri; dan (4) pengambilan keputusan inkremental utamanya 


\section{JURNALKU}

Volume 1 No. 2, Juni 2021

diberikan terhadap desain yang luas, di mana penyesuaian marjinal sering disebabkan oleh konsekuensi yang tidak diprediksi dari keputusan-keputusan sebelumnya.

Selanjutnya pada awal tahun 1990-an, Moravcsik (1993) mengembangan liberal intergovernmentalism atau intergovermentalisme liberal, untuk menjelaskan proses integrasi, menyarankan kombinasi teori liberal untuk menjelaskan tatanan nasional dan teori intergovernmental dari negosisasi antar negara untuk menjelaskan hasil substansial (Moravcsik, 1993).

FDI merupakan faktor kunci dalam integrasi ekonomi internasional. Dengan kerangka kerja kebijakan yang tepat, FDI dapat menawarkan kestabilan ekonomi, mendorong perkembangan ekonomi, dan meningkatkan kesejahteraan masyarakat (OECD, 2008). FDI merupakan satu dari tiga komponen arus modal internasional, selain investasi portofolio dan arus lain seperti pinjaman bank (Protsenko, 2003).

OECD mengemukakan bahwa FDI adalah pendirian interest - perusahaan termasuk dalam pengertian interest - di suatu ekonomi - istilah yang biasa digunakan organisasi ekonomi dalam menyebut negara - yang berbeda dari ekonomi sumber modal, atau investor. Investor tersebut, setidaknya memiliki $10 \%$ suara di RUPS perusahaan yang didirikan di ekonomi lain itu. FDI termasuk juga transaksi atau posisi keuangan masuk atau keluar antara interest yang dimiliki langsung maupun tidak langsung (OECD, 2008). Sedangkan menurut International Monetary Fund (1993), FDI adalah "an investment made to acquire lasting interest in enterprises operating outside of the economy of the investor."

Investor bertujuan untuk mendapatkan suara efektif pada manajemen sebuah entitas. Investor asing yang melakukan investasi pada entitas di ekonomi selain ekonomi investor tersebut disebut direct investor. Entitas yang dimiliki oleh investor asing dapat berupa sebuah perusahaan terbuka atau bukan perusahaan terbuka, berupa cabang, atau anak perusahaan, dan disebut direct investment enterprise. Seperti halnya OECD, IMF menyatakan bahwa kepemilikan minimal adalah $10 \%$.

Menurut Agiomirgianakis et al. (2003) FDI merupakan arus model yang dihasilkan oleh perilaku dari multinationals enterprise (yang selanjutnya disingkat MNE). Oleh karenanya, faktor-faktor yang mempengaruhi perilaku dari MNEs mungkin juga mempengaruhi magnitude dan arah FDI itu sendiri. Faktor-faktor yang mempengaruhi FDI itu kemudian disebut oleh banyak peneliti adalah determinan dari FDI, antara lain: market size, openness, biaya tenaga kerja, risiko politik, infrastruktur, iklim investasi dan pajak.

Riset terkait yang membahas hubungan integrasi regional dengan arus masuk FDI telah dilakukan oleh beberapa peneliti. Beberapa penelitian mencoba mendeskripsikan fenomena bertumbuhnya jumlah perjanjian integrasi regional dan memprediksi bagaimana hal tersebut akan mempengaruhi FDI (UNCTAD, 1996; Te Velde dan Fahnbulleh, 2003).

Pramadhani, Bissoondeeal, dan Driffiled (2007) menganalisis hubungan FDI, perdagangan, dan pertumbuhan ekonomi, dan menyimpulkan bahwa, investasi yang masuk ke Indonesia akan meningkatkan ekspor, dari ekspor tersebut akan meningkatkan FDI masuk ke Indonesia. Penelitian Atoyebi et al. (2012) Arfa, Aliasuddin, dan Nasir (2015) Saputra \& Kesumajaya (2016) menemukan pengaruh investasi, ekspor, dan impor terhadap gerak pertumbuhan ekonomi suatu negara atau kawasan. Penelitian yang dilakaukan oleh Alguacil, Cuadros, dan Orts (2002) di Meksiko menunjukan bahwa FDI sektor manufaktur berkontribusi dalam mendorong pertumbuhan ekonomi. Riyadi (1998) dengan model ekonometrik juga menemukan hubungan positif dan signifikan antara arus masuk FDI dengan pertumbuhan ekonomi melalui sektor manufaktur dan sektor jasa. 


\section{JURNALKU}

Volume 1 No. 2, Juni 2021

\section{METODE}

Penelitian menggunakan metode kualitatif dengan pendekatan fenomenologi. Penulis mempelajari, memproses, dan menelaah sumber pustaka tertulis yang berhubungan dengan permasalahan yang dibahas dalam penelitian ini. Sumber literatur tersebut antara lain: artikel jurnal, peraturan perundang-undangan dan produk jurnalistik yang relevan.

\section{HASIL DAN PEMBAHASAN}

FDI yang masuk ke ASEAN pada tahun 2019 mencapai USD 158 miliar. Angka tersebut dicapai akibat kinerja ekonomi negara ASEAN yang terus menguat di dunia, dan juga meningkatnya peran ASEAN dalam politik internasional. Namun hal tersebut juga tidak lepas dari mulai pulihnya ekonomi negara maju - yang merupakan sumber utama FDI ke ASEAN setelah krisis finasial pada 2008 melanda hampir seluruh negara.

Jika kita mundur beberapa dekade ke belakang, kita dapat melihat pergerakan FDI ke ASEAN yang juga terus menguat sejak awal tahun 1990an. Pada Gambar 1 dapat dilihat bahwa tren FDI ke ASEAN sangat rendah dari tahun 1970an hingga medio 1980an. Namun FDI ke ASEAN menunjukan tren yang mulai positif setelah medio 1980an dan meroket pada 1993. Pada tahun 1993, ASEAN Free Trade Agreement mulai diimplementasikan. Hal ini menjadi insentif para investor dari negara maju untuk berinvestasi di ASEAN, karena dengan adanya area pasar bebas, pergerakan barang akan menjadi lebih murah. Investor akan menamkan modalnya di salah satu negara ASEAN untuk mencakup seluruh pasarnya di region ASEAN, sehingga pada tahun tersebut FDI ke ASEAN meroket. Tren positif tersebut terus berlanjut sampai krisis finansial pada tahun 1997/1998 mempengaruhi hampir seluruh negara ASEAN. Pada krisis tersebut, FDI masuk ke ASEAN berkurang sekitar 23\% (Ismail, Smith, \& Kugler, 2009). Penurunan ini disebabkan rendahnya arus FDI dari Jepang, Republik Korea, dan investasi intra-ASEAN sendiri. Akibat dari time-lag effect pada krisis finansial 1997/1998 yang melemahkan sektor korporasi ASEAN, sehingga menyebabkan investasi intra-ASEAN menurun.

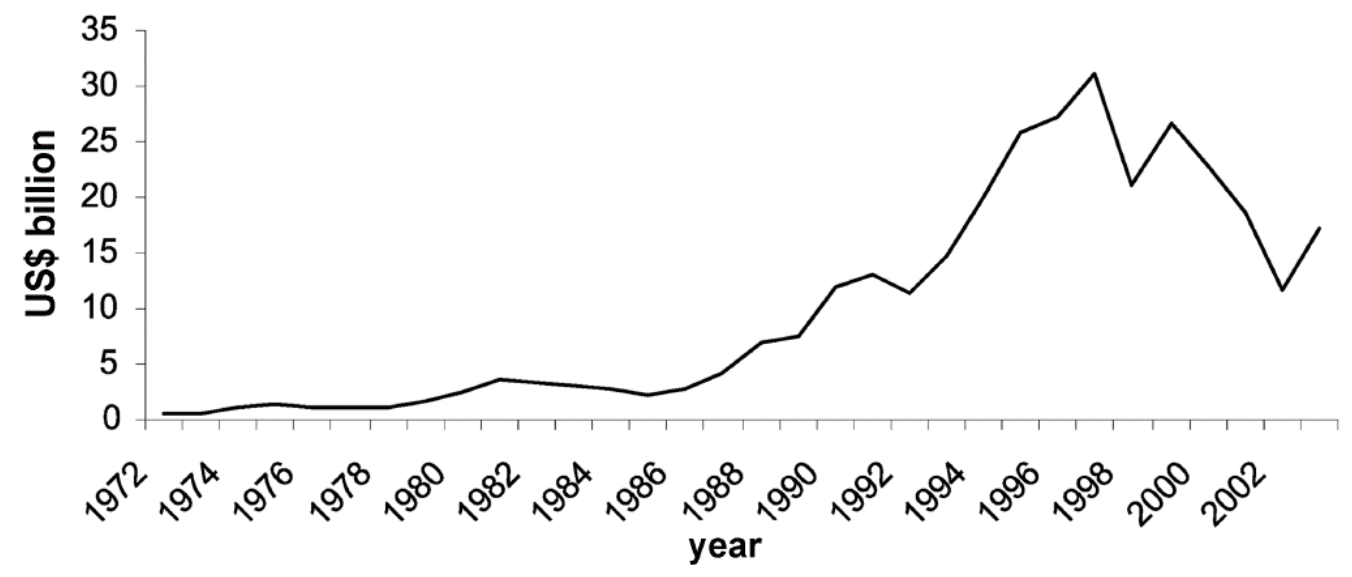

Gambar 1

Total Arus Masuk FDI ke Negara ASEAN, 1970-2003

Sumber: World Development Indicators, 2004

Munculnya berbagai organisasi integrasi regional (OIR) di seluruh dunia tentunya dilatarbelakangi dengan tujuan tertentu. Pastinya setiap negara yang menjadi anggota OIR, bermotivasi dengan bergabungnya negaranya, kepentingan individu dan kolektif akan terealisasi. Dalam integrasi regional, aktor politik ASEAN idealnya akan melihat suatu masalah pada lingkup yang lebih luas, yaitu kawasan secara kolektif, tidak lagi hanya dalam level domestik. Aktor politik dari Indonesia, Malaysia, Singapura, dan negara anggota lain, akan menggeser agenda, aktivitas, loyalitas, dan ekspektasinya menuju area kolektif. Para aktor 


\section{JURNALKU}

Volume 1 No. 2, Juni 2021

tersebut harus mencapai konsesual atas pembahasan dan negosiasi mengenai apa yang harus ASEAN lakukan, akan lakukan, dan bagaimana melakukannya pada level interaksi politik regional.

Ketika melakukan interaksi politik regional ini, ASEAN dimudahkan dengan adanya platform yang selama ini telah terbentuk. Platform tersebut ialah ASEAN Summit yang sejak 1995, secara rutin terus digelar setiap tahunnya. Dalam pertemuan ini, para pemimpin ASEAN bertemu dan membahas masalah dan isu di berbagai bidang, seperti ekonomi, politik, budaya, social, hingga keamanan.

Platform yang telah terbentuk ini tentunya menjadi sarana paling mudah dalam membahas mengenai isu kelanjutan integrasi regional. Para aktor politik dapat terus secara intens memetakan hambatan dalam melaksanakan integrasi yang lebih lanjut, membahas langkah-langkah yang perlu dilakukan, dan evaluasi atas realitas. Selanjutnya penulis dalam sub bab ini akan menganalisis mengenai pengaruh integrasi regional dalam menarik FDI, dan tindakan dan langkah yang perlu dilakukan dalam mencapainya, bedasarkan teori determinan FDI.

\section{Ukuran Pasar (Market Size)}

Market size merupakan salah satu determinan FDI. Market size yang diukur dengan PDB merupakan determinan paling penting dalam menentukan arah FDI. Investor atau MNE tidak lagi memandang negara-negara ASEAN sebagai pasar yang terpisah dengan terintegrasinya beberapa negara di ASEAN. MNE dan investor akan memandang ASEAN sebagai satu kesatuan pasar yang terintegrasi, sehingga cakupan pasar yang jauh lebih luas sebelumnya.

Market size yang besar penting untuk pemanfaatan sumber daya yang efisien dan eksploitasi ekonomi skala. Ketika market size tumbuh pada titik tertentu, FDI juga akan meningkat dengan ekspansi lanjutan. Bukti dari peristiwa di beberapa negara lain juga menjelaskan hal yang serupa. Penelitian oleh Scaperlanda \& Mauer (1969) pada determinan FDI Amerika Serikat di European Economic Community, FDI tidak akan diarahkan ke lokasi lain, selama market size lokasi tujuan FDI memenuhi implementasi efektif dari teknologi produksi. Ketika investor atau MNE membangun fungsi produksi, arus modal akan bertambah seiring dengan pertumbuhan pemintaan. Peran pertumbuhan permintaan didasarkan oleh hubungan antara pemintaan agregat, dan modal yang dibutuhkan untuk memenuhi permintaan. Sehingga ada hubungan positif antara arus modal dengan pertumbuhan PDB (growth rate of GDP).

Sebagai contoh, apabila suatu MNE akan melakukan FDI di Indonesia, maka akan mencakup pasar dengan populasi 258.705.000 jiwa (2016) dengan kapasitas ekonomi 12 ribu triliun rupiah. Sedangkan secara kolektif ASEAN, MNE akan mencakup pasar dengan total populasi 634.485.000 jiwa, dengan kapasitas ekonomi 34 ribu triliun. Dengan jumlah konsumen potensial yang jumlahnya besar, MNE akan tertarik untuk memilih menempatkan modalnya di ASEAN. Potensi ini sangat baik apabila dimanfaatkan oleh MNE yang ingin melebarkan sayap usahanya ke teritori baru. MNE paling berpeluang melebarkan sayap usahanya malalui FDI horizontal.

MNE melakukan FDI horizontal di ASEAN dengan maksud untuk mencakup pasar baru yang potensial. FDI horizontal MNE dapat dilakukan dengan dua cara. Pertama, dengan mendirikan entitas baru yang melakukan aktivitas ekonomi yang sama dengan entitas induknya di negara sumber. Kedua, mengakuisisi entitas yang sudah ada di negara tujuan, yang melakukan aktivitas eknomi sama dengan induk di negara sumber.

Mendirikan entitas baru baik dilakukan apabila pelaku aktivitas ekonomi di daerah tujuan tidak memiliki market share yang besar dan kuat, sehingga produk baru lebih mudah penetrasi ke pasar. Sebagai contoh bagaimana Ikea mulai masuk ke pasar Indonesia dengan 


\section{JURNALKU}

Volume 1 No. 2, Juni 2021

namanya sendiri. Hal tersebut disebabkan tidak ada pemain di bidang perlengkapan rumah tangga yang dominan di Indonesia, dan juga merk Ikea yang telah terkenal di dunia membuatnya mudah penetrasi ke pasar Indonesia.

\section{Openess atau Keterbukaan}

Keterbukaan suatu negara atau daerah sangat mempengaruhi keputusan untuk melakukan investasi. Negara yang terbuka secara ekonomi lebih aktif dalam melakukan perdagangan dengan negara lain. Biasanya negara tersebut memiliki tarif perdagangan yang rendah sebagai insentif perdagangan. Hal ini menjadi daya tarik bagi investor untuk menanamkan modalnya di negara tersebut. Faktor ini sangat relevan unutk jenis FDI vertikal, dikarenakan lebih mudahnya arus perpindahan barang dan jasa akibat biaya yang rendah. Investor akan membuka cabang rantai produksinya di negara tujuan investasi untuk menyuplai aktivitas ekonominya di negara tujuan investasi lain ataupun negara sumber.

Deteminan ini telah menjadi bahasan penting di antara aktor politik dalam lingkup interaksi tingkat ASEAN. Dengan adanya AFTA - yaitu upaya para negara anggota ASEAN untuk menurunkan tarif perdagangan di ASEAN - serta penghambat perdagangan non tarif, perdagangan intra-ASEAN terus meningkat. Selain itu, ASEAN juga memiliki perjanjian perdagangan strategis dengan mitra ekonominya di antaranya ialah, Cina dan Uni Eropa.

Platform yang relah terbentuk dan hubungan ekonomi yang telah terjalin dengan Cina dan Uni Eropa, - yang juga merupakan negara sumber investasi - ASEAN seharusnya dapat menjadi negara tujuan FDI vertikal utama dari dua pemain ekonomi global dominan tersebut. ASEAN dapat dijadikan tempat pemrosesan barang - juga sebagai bagian rantai suplai sebelum dikirim ke negara sumber investasi Cina, Uni Eropa, dan lain-lain atau dikirim ke negara ASEAN lain untuk diproses lebih lanjut ataupun dikonsumsi, karena rendahnya biaya unutk perdagangan barang dan jasa intra-ASEAN.

\section{Biaya Tenaga Kerja}

Mayoritas negara ASEAN memiliki upah minimum yang lebih rendah daripada ratarata negara OECD, di mana sumber investasi kebanyakan berasal. Sehingga hal ini menarik bagi investor untuk menekan biaya produksinya dengan membuat entitas di negara ASEAN dan mempekerjakan warga lokal untuk biaya yang lebih rendah. Sebagai perbandingan, menurut data OECD, Australia adalah negara dengan upah minimum tertinggi dibandingkan dengan negara OECD yang lain atau bahkan dunia, yaitu 9,54 dolar AS per jam, dibandingkan dengan Filipina yaitu upah minimum tertinggi di ASEAN yakni 10,05 dolar AS per hari.

Disparitas upah minimum yang sangat besar itu, tentunya akan membuat investor jauh lebih hemat apabila memproduksi barang atau jasa di negara dengan upah minimum yang lebih rendah. Pasalnya biaya tenaga kerja (direct labour cost) merupakan komponen penting dalam membentuk harga pokok barang. Investor akan berinvestasi lebih di lokasi di mana biaya tenaga kerja yang rendah, karena di satu sisi akan menekan beban, dan akan menyerap lebih banyak tenaga kerja di sisi lainnya. Hal ini sejalan dengan studi yang dilakukan Irawan (2013) menunjukan, upah memiliki pengaruh yang signifikan dalam mempromosikan FDI

Determinan ini apabila disertai juga dengan rezim ekonomi yang terbuka sebagaimana dibahas pada bagian poin huruf $b$, akan lebih menarik bagi investor untuk mengambil keputusan lokasi FDI. Namun hal ini tidak serta merta akan menjadi determinan andalan ASEAN dalam menarik FDI, dikarenakan masih banyak lokasi investasi lain yang juga memiliki upah minimum yang serupa atau lebih rendah. Selain itu perlu diingatkan kembali bahwa determinan FDI ini akan berfungsi lebih optimal apabila suatu keunggulan atas determinan-determinan tersebut dimiliki secara kolektif.

\section{Risiko Politik}

Berdasarkan penelitian empiris, sebenarnya korelasi antara risiko politik dan FDI masih belum jelas. Tidak terdapat korelasi pasti apakah risiko politik mempengaruhi keputusan dalam 


\section{JURNALKU}

Volume 1 No. 2, Juni 2021

menentukan lokasi investasi. Namun pada dasarnya, dalam melakukan investasi, politik sangat berperan penting yaitu dalam membentuk regulasi, hukum, dan keamanan dalam berinvestasi. Sehingga risiko-risiko seperti instabilitas politik (Edwards, 1990) yaitu pergantian kekuasaan yang tiba-tiba dan political violence seperti kudeta, penculikan menjadi perhatiaan penting investor.

Indeks Instabilitas Politik yang dirilis The Economist pada 2007 mendeskripsikan intabilitas politik sebagai ancaman terhadap pemerintah oleh protes sosial. Jika merujuk pada indeks Instabilitas Politik oleh The Economist, negara-negara ASEAN berapa pada posisi yang tidak terlalu baik. Kamboja contohnya, berada di posisi ke empat paling rentan terhadap protes sosial. Indonesia, Malaysia, Filipina, dan Myanmar berada di kategori risiko tinggi. Singapura, Lao PDR, dan Vietnam berada di posisi moderat. Artinya secara kolektif, rsisiko politik di kawasan ASEAN pada 2007 masih cukup tinggi, sebagaimana seperti banyak negara berkembang lainnya yang menjadi tujuan investasi.

Risiko politik ini sebetulnya dapat direduksi dengan menjalankan komitmen bersama negara-negara ASEAN untuk mewujudkan stabilitas politik di kawasan dengan risiko rendah. Hal tersebut dapat dilakukan dengan mempromosikan transparansi dan akuntabiltas adminitrasi, asistensi hukum, bantuan advokasi dan bantuan humanitarian.

\section{Infrastruktur}

Infratruktur merupakan determinan FDI yang menarik, karena memiliki keuntungan masing-masing pada dua kondisi yang berbeda. Dua kondisi berbeda tersebut ialah lokasi tujuan investasi dengan kondisi infrastruktur yang baik serta memadai, dan yang lainnya adalah lokasi tujuan investasi dengan kondisi infrastruktur yang buruk.

Kondisi yang pertama ialah lokasi investasi dengan infrastruktur yang baik dan memadai. Infratruktur merupakan komponen penunjang dalam melakukan aktivitas ekonomi. Selain itu, dengan adanya infrastruktur, juga mengurangi biaya yang dikeluarkan investor, seperti membangun jalan yang memadai untuk dilalui barangnya, atau pembangkit listrik sendiri untuk menjalankan pabriknya. Infrastruktur sepeti jalan, rel, bandar udara, dan pelabuhan juga mempermudah pergerakan arus barang, sehingga bisnis lebih mudah mendistribusikan barang produskinya atau bahan baku untuk produksinya dari satu tempat ke tempat lain.

Secara umum kondisi infrastruktur ASEAN berada dalam keadaan yang memadai. Seluruh negara ASEAN terhubung melalui darat, laut, dan udara. Lokasi yang strategis sebagai jalur perdagangan juga telah membuat ASEAN siap dengan infrastrukturnya. Singapura memiliki pelabuhan tersibuk kedua di dunia, serta beberapa pelabuhan penting dunia di selat malak yang berada di Indonesia, dan Malaysia.

Jika dilihat dari infrastruktur jalan, maka negara dengan panjang jalan terpendek adalah Singapura. Panjang jalan di Singapura hanya $3.496 \mathrm{~km}$ - kedua terendah di ASEAN, setelah Brunei - dibandingkan dengan Indonesia 518.153, yang merupakan terpanjang di ASEAN. Namun jika dibandingkan dengan luas area daratan negaranya, Singapura yang luas daratannya hanya $709 \mathrm{~km}^{2}$ menjadi negara dengan konektivitas tertinggi yaitu $4,93 \mathrm{~km}$ jalan, setiap $1 \mathrm{~km}^{2}$ daratan. Di antara ASEAN 5, Malaysia kedua terbaik yakni 0,73 km jalan $/ \mathrm{km}^{2}$, selanjutnya Thailand, Indonesia, dan terakhir Filipina. Dengan infrastruktur yang baik sehingga konektivitas tinggi, bisnis menjadi lebih muda untuk memindahkan barang dan jasa, hal ini yang dapat dijadikan pertimbangan oleh investor dalam menentukan lokasi FDI. Sehingga sekali lagi Singapura memang negara dengan FDI tertinggi di ASEAN.

Kondisi kedua ialah infrastruktur yang buruk. Kondisi tersebut juga dapat menarik FDI ke sebuah lokasi investasi. Pasalnya, kondisi infratruktur yang buruk juga peluang bagi investor untuk berinvestasi membangun infrastruktur. Seperti Cina dan Jepang yang menjadi investor utama dalam pembangunan infrastruktur di Indonesia. Cina yang berinvestasi pada 


\section{JURNALKU}

Volume 1 No. 2, Juni 2021

pembangunan kereta cepat di Indonesia, Jepang berinvestasi pada pembangunan transportasi massal, merupakan contoh bagaimana ketersediaan infraktruktur juga dapat menarik peluang investasi.

\section{Iklim Investasi}

Anh \& Cieślik (2015) berpendapat, bahwa Index of Economic Freedom ialah parameter termudah untuk mengukur iklim investasi suatu negara. Komponen-komponen yang digunakan untuk mengukur indeks tersebut ialah: property rights; integritas pemerintah; efektivitas kehakiman atau lembaga peradilan; beban pajak; belanja pemerintah; kesehatan fiskal; kebebasan berusaha; kebebasan tenaga kerja; kebebasan moneter; kebebasan perdagangan; kebebasan investasi; dan kebebasan finansial.

Data di bawah menunjukan posisi dan skor yang diperoleh negara-negara anggota ASEAN. Data tersebut menunjukan negara ASEAN dengan skor tertinggi ialah Singapura, yakni 88,8 , kedua tertinggi di dunia. Hal ini didukung dengan fakta bahwa Singapura menarik FDI paling banyak daripada negara ASEAN lain, maka iklim investasi memang memiliki pengaruh yang besar dalam menarik FDI. Dengan iklim investasi yang baik, Singapura dapat menjadi agen penarik FDI ke ASEAN, serta juga dapat dijadikan model dan benchmark negara ASEAN lain, dalam menciptakan iklim investasi kolektif yang baik. Tetapi walaupun posisi negara ASEAN lain relatif tidak sebaik Singapura, mayoritas negara tersebut memiliki skor yang di atas rata-rata dunia, yaitu 61,1. Setidaknya hanya 4 negara ASEAN yang memiliki skor di bawah rata-rata. Skor 4 negara tersebut pun angkanya masih tidak terpaut jauh dari rata-rata dunia. Sehingga secara keseluruhan, regional ASEAN memiliki skor yang sangat baik sebagai tujuan FDI dibandingkan dengan lokasi lain - lokasi ideal FDI adalah negara berkembang seperti wilayah Afrika dan Amerika Latin.

\section{Tabel 1}

Index of Economic Freedom

\begin{tabular}{|c|c|c|}
\hline Urutan Dunia & Negara & Skor Indeks (maks. 100) \\
\hline $\mathbf{2}$ & Singapura & 88,8 \\
\hline $\mathbf{2 2}$ & Malaysia & 74,5 \\
\hline $\mathbf{5 3}$ & Thailand & 67,1 \\
\hline $\mathbf{6 1}$ & Filipina & 65,0 \\
\hline $\mathbf{6 9}$ & Indonesia & 64,2 \\
\hline $\mathbf{7 0}$ & Brunei Darussalam & 64,2 \\
\hline $\mathbf{1 0 1}$ & Kamboja & 58,7 \\
\hline $\mathbf{1 3 5}$ & Myanmar & 53,9 \\
\hline $\mathbf{1 3 8}$ & Lao PDR & 53,6 \\
\hline
\end{tabular}

Sumber: https://www.heritage.org/index/. 2018

Menciptakan iklim investasi yang lebih baik, merupakan salah satu poin penting yang ditekankan oleh para aktor politik ASEAN dalam cetak biru ASEAN Economic Community (AEC) 2015. Cetak biru tersebut menyebutkan bahwa AEC berkomitmen untuk membuat lingkungan investasi ASEAN menjadi lebih atraktif dengan membuat rezim investasi yang terbuka, transparan, dan dapat diprediksi. Poin tersebut dicapai dengan mendorong implementasi ASEAN Comprehensive Investment Agreement (ACIA). ACIA memberikan: liberalisasi investasi pada sektor manufaktur, agrikultur, perikanan, jasa, dan sektor strategis lainnya; penguatan pelindungan investasi; dan transparansi dari regulasi investasi.

Poin penting dari cetak biru mengenai penguatan iklim investasi tersebut sejatinya akan membuat wilayah ASEAN menjadi lebih atraktif, akibat investor akan lebih merasa aman untuk berinvestasi dan kepastian hukum dari otoritras tujuan investasi. Kerja sama ini juga dapat 


\section{JURNALKU}

Volume 1 No. 2, Juni 2021

dijadikan ajang benchmark dan diskursi mengenai apa yang harus dilakukan, apa yang dapat dilakukan, dan bagaimana melakukan langkah-langkah dalam mencapai iklim investasi yang diharapkan.

Pajak

Telah dibahas pada bagian sebelumnya, para peneliti memiliki pendapat berbeda mengenai apakah pajak benar dapat mempengaruhi keputusan investor dalam melakukan FDI. Irawan (2013) berpendapat bahwa variabel pajak memiliki pengaruh yang bervariasi dalam menarik FDI dari perspektif negara sumber (Jepang, Republik Korea, dan Amerika Serikat). Dalam studinya menunjukan, bahwa dari perspektif Jepang, tarif pajak dan tax holiday, bersama dengan PDB sangat signifikan dalam mempengaruhi arus keluar FDI. Walaupun dalam beberapa kasus tarif pajak badan memiliki hubungan negatif dengan arus FDI, dalam perspektif Korea Selatan variabel ini tidak memiliki efek yang signifikan. Sedangkan dari perspektif Amerika Serikat, studi Irawan (2013) menunjukan bahwa tarif pajak badan memiliki pengaruh yang sangat signifikan bagi investor Amerika Serikat dalam menentukan lokasi FDI. Tax holiday juga memengaruhi investasi meskipun tidak signifikan.

Tabel 1

Arus Masuk FDI ke Negara ASEAN

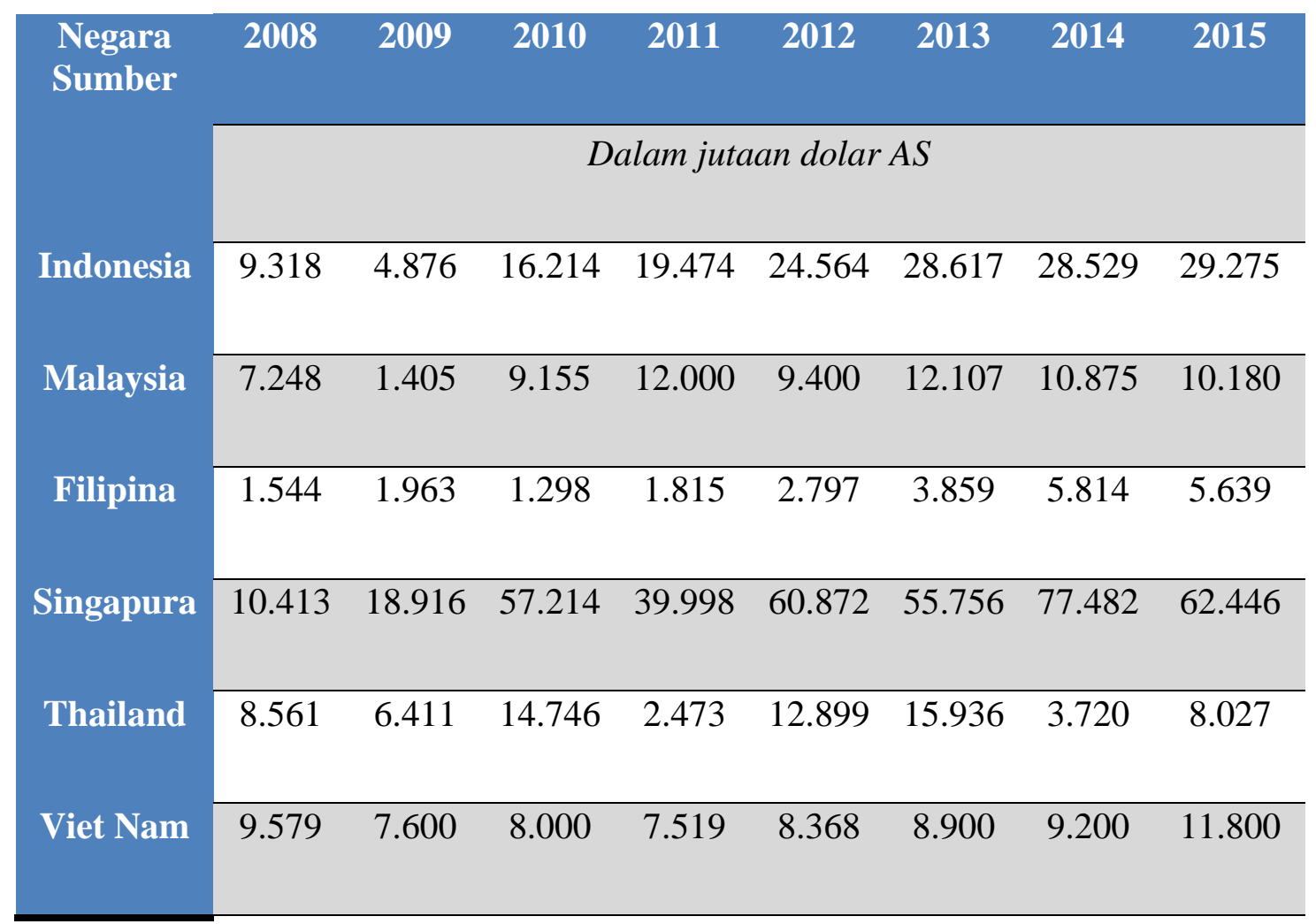

Sumber: Sekretariat ASEAN, ASEAN Yearbook, 2017 dan BKPM, 2016

Indonesia sebagai negara sumber memandang tarif pajak badan sangat jelas memengaruhi arus masuk FDI. Dapat diperhatikan pada Tabel 2, bahwa jumlah FDI masuk ke Indonesia meroket saat 2010. Pada tahun tersebut Indonesia menurunkan tarif pajak badannya dari $28 \%$ ke $25 \%$ untuk membuat negaranya lebih kompetitif di wilayah ASEAN.

Selain Indonesia, beberapa negara ASEAN lain juga mengalami kenaikan arus masuk FDI ketika menurunkan tarif pajak badannya. Singapura mengalami kenaikan arus masuk FDI pada 2010 sejumlah 202\%, ketika pada tahun 2010 menurun kan tarif pajak badannya dari 18\% ke $17 \%$. Thailand juga mengalami hal yang sama ketika arus FDI masuk bertambah $402 \%$ di tahun 2012 ketika tarif pajak badan turun dari $30 \%$ ke 23\%. Dari pemaparan di atas jelas dapat 


\section{JURNALKU}

Volume 1 No. 2, Juni 2021

disimpulkan bahwa terdapat hubungan negatif antara tarif pajak badan dengan arus masuk FDI, hal ini sejalan dengan studi Klemm \& Van Parys (2010).

\section{Pengaruh FDI terhadap Pertumbuhan Ekonomi Indonesia}

Hampir semua studi empiris mengenai pengaruh FDI terhadap pertumbuhan ekonomi menyatakan terdapat hubungan positif antar keduanya. Alasannya karena FDI berkontribusi terhadap stimulasi peningkatan modal agregat di suatu negara, juga eksternalitas positif pada ketersediaan teknologi yang dimiliki entitas lokal. Effendi \& Soemantri (2003) berargumen bahwa FDI memiliki efek positif terhadap pertumbuhan ekonomi karena terjadinya transfer teknologi dan keahlian manajerial, pengenalan teknologi produksi baru, dan akses terhadap jaringan internasional.

Melihat argumen Effendi \& Soemantri (2003), dapat dipahami karena dengan masuknya FDI, MNE akan membawa teknologi yang mereka punya untuk dipakai di negara tujuan, dengan alasan efisiensi produksi. Efisiensi itu mengakibatkan peningkatan produksi dalam negeri lebih dari yang sebelumnya. Selain itu, dibawahnya teknologi baru juga dapat membantu bisnis lokal unutk menggunakan tekonologi serupa, berkat spillover effect, sehingga semakin banyak bisnis yang menggunakan teknologi yang lebih efisien.

Menurut World Investment Report (2002), secara umum FDI dapat meningkatkan ekspor melalui: (1) menambah modal dalam negeri untuk ekspor; (2) menransfer teknologi dan produk baru untuk ekspor; memberikan akses kepada pasar baru atau asing; dan (3) menyediakan pelatihan kepada tenaga kerja dalam negeri dalam bidang teknis dan manajemen.

Peningkatkan ekspor dapat meningkatkan pertumbuhan ekonomi, karena ekspor merupakan stimulan penting dalam merangsang pertumbuhan ekonomi sebuah negara. Akses terhadap pasar yang baru atau pasar asing juga dapat meningkatkan pertumbuhan ekonomi. Pasar yang baru artinya terdapat perluasan basis konsumen, sehingga meningkatkan penjualan dan pendapatan bisnis. FDI juga menyediakan pelatihan tenaga kerja yang sangat menguntungkan bagis pertumbuhan ekonomi. Perbaikan human capital dianggap bagi banyak studi dapat mendorong pertumbuhan ekonomi. Tenaga kerja mendapat pengetahuan baru tentang bagaimana melakukan aktivitas ekonomi lebih efisien dengan sumber daya seminimal mungkin untuk mendapatkan produksi yang maksimal, melalui pelatihan.

Masuknya FDI ke Indonesia otomatis disertai dengan meningkatnya penyerapan tenaga kerja lokal. Perusahaan multinasional cenderung mempekerjakan tenaga kerja lokal untuk melakukan proses produksi karena biaya tenaga kerja yang lebih murah, daripada mendatangkan pekerja dari negara sumber. Arus masuk FDI ke Indonesia seharusnya dimanfaatkan untuk mengakomodir peningkatan jumlah angkatan kerja, juga optimalisasi bonus demografi Indonesia pada tahun 2030. Selain itu, hal ini juga yang menjadi determinan investor unutk menetukan lokasi investasi, seperti yang telah dibahas pada bagian sebelumnya. Terserapnya tenaga kerja, menyebabkan FDI lebih dipreferensikan daripada investasi portofolio oleh Indonesia, karena menurunkan angka pengangguran dan menggerakan ekonomi lokal dimana FDI berada.

Terserapnya tenaga kerja tentu berimplikasi terhadap daya beli masyarakat yang meningkat. Sehingga meningkatnya disposable income masyarakat yang dapat dibelanjakan untuk konsumsi. Dengan terjadinya hal itu, dapat menyebabkan multiplier effect, dimana suatu aktivitas ekonomi yang meningkat, menyebabkan aktivitas ekonomi lainnya yang berhubungan juga meningkat.

Misal suatu FDI masuk ke Indonesia untuk membangun sebuah pabrik sepatu. Ketika membangun pabrik tersebut, perusahaan multinasional (Multinational enterprises - MNE) akan membutuhkan tenaga pembangun pabrik tersebut. Ketika berkerja unutk membangun pabrik, pekerja tersebut akan mendapat upah, sebuah peningkatan daya beli, lalu para pekerja tersebut 


\section{JURNALKU}

Volume 1 No. 2, Juni 2021

membelanjakan upahnya untuk membeli beras, yang menyebabkan peningkatan permintaan atas beras, sehingga juga meningkatkan permintaan atas bibit beras.

Contoh lainnya ialah ketika MNE produsen sepeda motor mengalami peningkatan penjualan. Peningkatan penjualan tersebut membuat MNE akan meningkatkan pembelian komponen sepeda motor kepada penyuplai. Terjadi peningkatan pendapatan penyuplai ban sepeda motor, produsen ban sepeda motor akan meningkatkan pembelian bahan baku ban, seperti karet sintetis, dan juga karet alami, yang juga meningkatkan pendapatan dua produsen bahan baku tersebut.

Jika kita cermati Gambar 2, di tahun 2010 Indonesia mengalami peningkatan FDI 232\% dari FDI masuk pada 2009. Di tahun yang sama, pertumbuhan PDB Indonesia mencapai 6,2\%, dari sebelumnya tahun 2009 4,6\%. Data ini menunjukan bahwa FDI merupakan salah satu jika bukan yang terpenting - faktor terpenting yang berkontribusi dalam peningkatan pertumbuhan PDB di Indonesia.

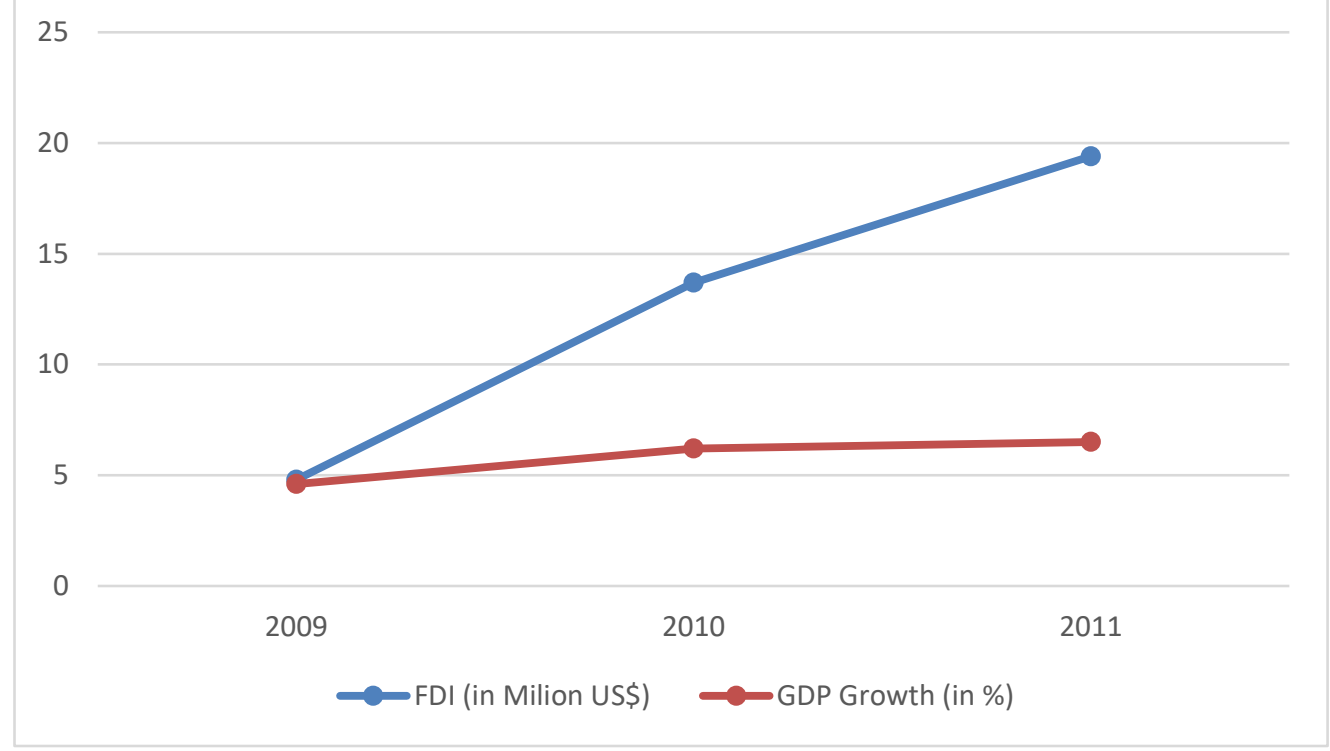

Gambar 2

Tren Arus Masuk FDI dan Pertumbuhan PDB Indonesia

Sumber:ASEAN Statistical Yearbook, 2017 dan BKPM, 2016

\section{Implikasi FDI terhadap Penerimaan Perpajakan Indonesia}

Sebagaimana yang telah dibahas pada bagian sebelumnya, beberapa literatur berpendapat bahwa FDI dan pajak memiliki hubungan yang terkait secara signifikan maupun tidak signifikan. Para pembuat kebijakan di pelbagai negara menganggap bahwa insentif pajak merupakan instrumen yang andal dalam menarik FDI masuk ke negaranya, walaupun perdebatan ini masih berlanjut dan terdapat dikotomi pendapat di antara peneliti. Oleh karena itu, hampir semua negara berkembang, berlomba-lomba membuat insentif pajak untuk memfasilitasi masuknya FDI ke negaranya.

Sebagai contoh, pembuat kebijakan Indonesia mengeluarkan Peraturan Menteri Keuangan Nomor 159 Tahun 2015 tentang Pemberian Fasilitas Pengurangan Pajak Penghasilan Badan (selanjutnya disebut PMK 159/2015) yang memberikan fasilitas tax holiday terhadap Penanaman Modal Asing (PMA) industri pionir, yang juga Wajib Pajak (yang selanjutnya disingkat WP) baru. Selain itu, untuk mendapatkan fasilitas ini, WP harus memenuhi beberapa syarat tertentu lainnya.

Peraturan tersebut memfasilitasi WP yang telah memenuhi syarat, dengan dapat diberikan pengurangan pajak penghasilan (yang selanjutnya disingkat $\mathrm{PPh}$ ) minimal $10 \%$ dan maksimal $100 \%$ dari pajak penghasilan badan yang terutang. Jangka waktu pemberian 


\section{JURNALKU}

Volume 1 No. 2, Juni 2021

pengurangan itu adalah paling singkat 5 tahun, dan paling lama 15 tahun. Jika kita lihat dari substansi fasilitas tersebut, tentu secara langsung Indonesia mengalami kerugian fiskal. Karena terdapat pengurangan penerimaan negara yang potensial sejumlah 10-100\% dari WP PMA industri pionir. Walaupun fasilitas seperti itu secara langsung memiliki dampak negatif terhadap penerimaan perpajakan, sejatinya tujuan dari fasilitas itu adalah untuk menarik FDI masuk ke Indonesia. Dengan meningkatnya FDI masuk Indonesia, menghasilkan penerimaan pajak tambahan dari pajak penghasilan orang pribadi - yang berkerja di MNE atau PMA, ataupun orang pribadi dan bisnis yang terkena multiplier effect - serta pajak penghasilan dari MNE yang memiliki laba berkelanjutan akibat fasilitas ini.

Studi yang dilakukan Balıkçığlu, Dalgıc, dan Fazlığlu (2016) pada kasus yang terjadi di Turki, mereka membagi dua efek yang dihasilkan oleh FDI, kuantitatif dan kualitatif. Kuantitatif yaitu kemampuan FDI untuk menarik aset ke sebuah negara, sedangkan kualitatif adalah efek FDI terhadap penerimaan perpajakan dan pendapatan tenaga kerja. Studi mereka menyimpulkan, bahwa fasilitas insentif pajak yang diberikan kepada MNE secara tidak langsung, meningkatkan penerimaan perpajakan dari pajak penghasilan orang pribadi. Mereka menyarankan agar pembuat kebijakan tidak seharusnya hanya mempertimbangkan efek kuantitif dari FDI, namun juga efek kualitatif yang juga penting. Studi ini mendukung analisis penulis bahwa masuknya FDI akan memiliki pengaruh atas peningkatan penerimaan perpajakan.

Selain itu studi yang dilakukan oleh Okey (2013) meneliti secara empiris pengaruh FDI ke delapan negara Afrika Barat dalam rentang 1989-2009, terhadap penerimaan perpajakan. Studi tersebut menemukan efek positif yang signifikan antara FDI dengan penerimaan perpajakan,penambahan $10 \%$ FDI, menghasilkan $4,78 \%$ peningkatan penerimaan perpajakan, serta FDI sektor pertambangan paling berkontribusi meningkatkan penerimaan perpajakan.

FDI memiliki efek positif terhadap penerimaan perpajakan melalui beberapa bentuk: Pajak Pertambahan Nilai (PPN); PPh orang pribadi dan badan; royalti; dan pajak perdagangan internasional. Peningkatan penerimaan dari PPN terjadi ketika FDI menciptakan aktivitas produksi barang dan jasa. Di mana terdapat penyerahan barang kena pajak (BKP) dan jasa kena pajak (JKP) yang harus dibayar PPN nya. FDI yang meningkatkan produksi barang dan jasa nasional tentunya juga akan meningkatkan penerimaan pajak dari PPN.

Masuknya FDI ke Indonesia, juga dapat menghasilkan peningkatan penerimaan $\mathrm{PPh}$ melalui ketersediaan lapangan kerja dan pengurangan tingkat pengangguran. Juga ditambah dengan fasilitas tax holiday PPh terutang WP badan, sehingga MNE seharusnya dapat meningkatkan remunerasi karyawannya, yang berujung pada meningkatnya $\mathrm{PPh}$ orang pribadi. Sebenarnya dengan adanya fasiltas PMK 159/2015, Indonesia berada di posisi win-win solusion. Karena secara langsung dengan adanya fasilitas itu penerimaan pajak berkurang, tetapi secara tidak langsung penerimaan pajak sektor lain yang bertambah.

Pengaruh FDI dalam bidang ekspor, yaitu memperkuat kapasitas ekspor dan memfasilitasi akses terhadap pasar global. Hal ini yang menghasilkan peningkatan penerimaan pajak dari perdagangan internasional. Telah dibahas pada bagian sebelumnya, bahwa pada tahun 2010, terdapat peningkatan jumlah arus masuk FDI ke Indonesia sebesar 232\%, di tahun yang sama jumlah ekspor Indonesia meningkat dari 116.510 juta dolar AS pada 2009, ke 157.779 juta dolar AS pada 2010, atau meningkat 35\%. Dengan peningkatan ekpor tersebut, bedasarkan data realisasi penerimaan perpajakan oleh Badan Pusat Statistik, Indonesia mendapat penerimaan pajak dari sektor perdagangan internasional sebesar 28 triliun rupiah, meningkat 10 triliun dari tahun 2009.

Akses terhadap pasar global menguntungkan bagi produsen dan pelaku ekonomi Indonesia pada umunya. Akses tersebut dapat digunakan untuk promosi produk lokal, juga melayani pasar baru. Dengan ada yang akses tersebut, produsen lokal dapat meningkatkan 


\section{JURNALKU}

Volume 1 No. 2, Juni 2021

penjualan serta laba, yang berujung peningkatan penerimaan perpajakan. Penerimaan perpajakan itu, dapat diperoleh dari PPh badan itu sendiri, atau $\mathrm{PPh}$ orang pribadi karyawannya, karena mendapat peningkatan remunerasi atas peningkatan penjualan.

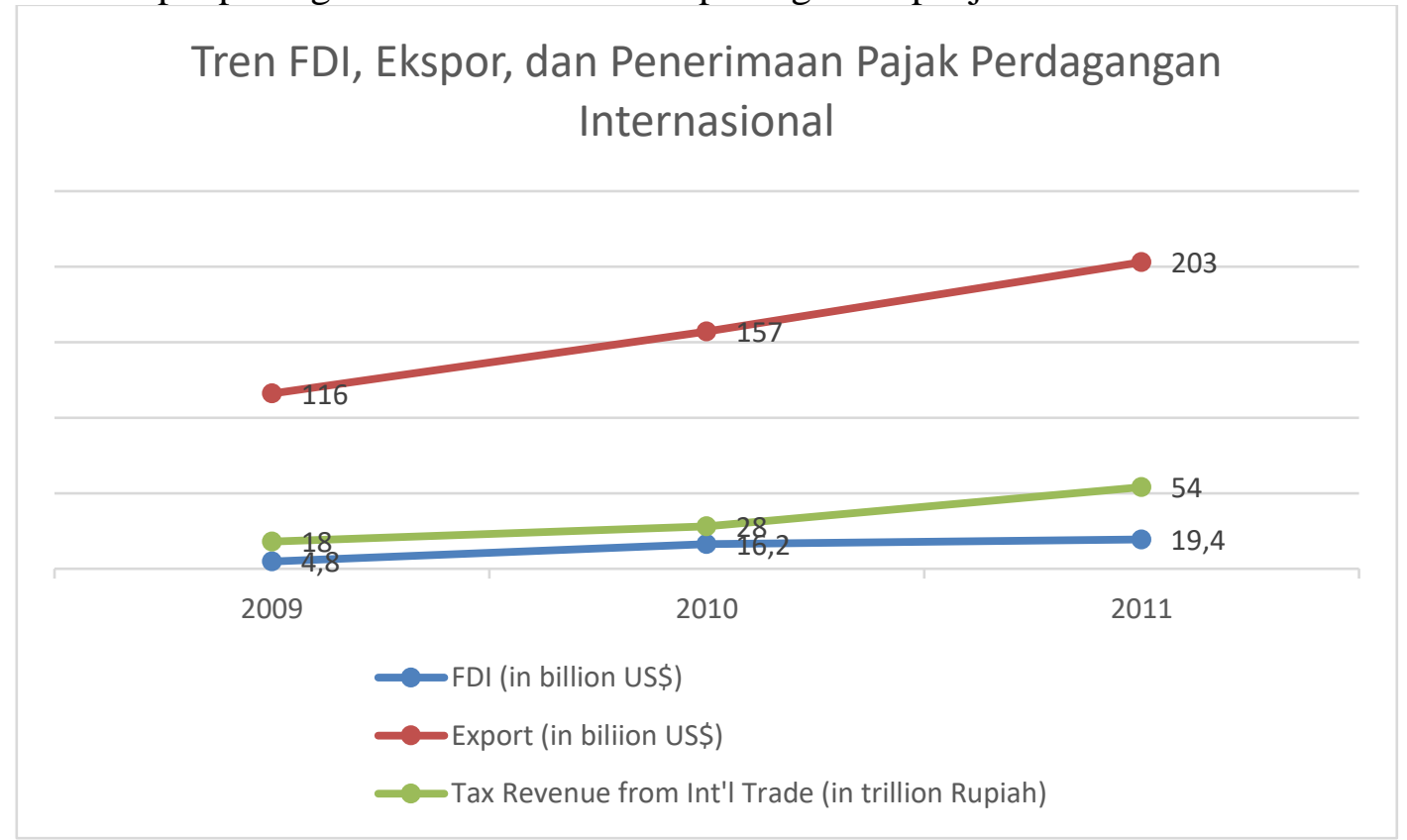

Gambar 3

Tren FDI, Ekspor, dan Penerimaan Perpajakan Perdagangan Internasional

Sumber: Sekretariat ASEAN, ASEAN Yearbook, 2017, BKPM, 2016, dan BPS, 2018

Hasil studi Okey (2013) berargumen bahwa kontributor FDI terbesar untuk peningkatan penerimaan perpajakan ialah sektor pertambangan. Di Indonesia sendiri, FDI tertinggi yang masuk adalah sektor pertambangan (BKPM, 2016) dengan total pada tahun 20134.816 juta dolar AS, atau $16 \%$ dari seluruh FDI masuk ke Indonesia. Dengan begitu, FDI masuk ke Indonesia sangat baik untuk mendorong peningkatan penerimaan perpajakan. Di sisi lain, FDI sektor pertambangan juga berkontribusi besar dalam penerimaan melalui royalti dalam pengelolaan sumber daya alam.

Sektor infrastruktur juga ikut terkena pengaruh atas masuknya FDI ke Indonesia. FDI masuk ke Indonesia mencapai nilai yang tinggi, pada tahun 2015 belanja infrastruktur melalui FDI mencapai 29,27 miliar dolar AS (PricewaterhouseCooper, 2016). Hal tersebut menunjukan komitmen administrasi ini untuk mengakselerasi pembangunan insfrastruktur, serta peluang Indonesia sebagai tujuan FDI sektor infrastruktur yang semakin atraktif. Meningkatnya ketersediaan infrastruktur, dan perbaikan kondisinya, membuat pergerakan barang dan jasa semakin lebih mudah, yang menghasilkan peningkatan penyerahan barang dan jasa juga. Sehingga Indonesia mendapatkan keuntungan dengan meningkatnya penerimaan perpajakan dari PPN, akibat peningkatan penyerahan barang dan jasa.

Arus masuk FDI ke kawasan ASEAN dipengaruhi oleh integrasi berbagai bidang mulai dari perdagangan, ekonomi, sosial, dan politik di ASEAN itu sendiri. Integrasi ASEAN menawarkan kondisi atas determinan yang lebih baik kepada setiap negara-negara anggota ASEAN. Sehingga kondisi setiap negara anggota menjadi lebih menarik sebagai lokasi tujuan FDI dari negara sumber.

FDI masuk ke kawasan ASEAN, khususnya Indonesia, berkontribusi atas pelbagai aktivitas produksi dalam negeri, ekspor dan impor, menciptakan dan menyerap tenaga kerja, dan memperkuat daya beli serta, menimbulkan multiplier effect terhadap ekonomi Indonesia. Sehingga FDI ikut berperan dalam meningkatkan pertumbuhan ekonomi Indonesia secara 


\section{JURNALKU}

Volume 1 No. 2, Juni 2021

keseluruhan. Dengan bertumbuhnya ekonomi, FDI juga artinya memiliki implikasi langsung dan tidak langsung terhadap penerimaan perpajakan Indonesia.

\section{PENUTUP}

\section{Simpulan}

Upaya menarik arus masuk FDI ke masing-masing negara ASEAN khusunya Indonesia, akan lebih menarik apabila kondisi ekonomi ASEAN terintegrasi. Ekonomi yang terintegrasi memeberikan keunggulan lebih pada setiap determinan FDI. Dalam hal market size ekonomi ASEAN yang terintegrasi memberikan keunggulan jauh yang lebih baik daripada ekonomi yang tidak terintegrasi, juga determinan market size merupakan determinan yang paling penting dalam menarik FDI.

Arus FDI terbukti meningkat ketika terjadinya setiap tahapan integrasi regional. Seperti yang terjadi pada pembentukan AFTA, FDI masuk ke ASEAN meningkat drastis lebih dari yang pernah terjadi sebelumnya. Hal ini membuktikan bahwa determinan penentu FDI meningkat ketika terjadinya integrasi. Tidak hanya terjadi di ASEAN, hal serupa juga terjadi di Mercosur, di mana ketika setelah pembentukan OIR merka, FDI masuk ke nagara anggota Mercosur juga perlahan meningkat daripada sebelumnya.

Walaupun tingkat integrasi regional ASEAN masih dibawah OIR lain seperti Uni Eropa, upaya menarik arus FDI melalui integrasi regional secara historis telah dilakukan secara gradual oleh ASEAN, dan terakhir dengan dibentuknya AEC. AEC dapat dijadikan platform ekonomi ASEAN yang komprehensif untuk mendorong agenda integrasi lebih tingkatan yang lebih jauh lagi. Platform tersebut dapat digunakan unutk memetakan kondisi dan peluang ekonomi, apa yang harus ASEAN lakukan, dan apa yang dapat ASEAN lakukan. Dengan tumbuhnya ASEAN, ke depannya ASEAN dapat menjadi pemain ekonomi penting di kawasan maupun dunia, atupun aktor politik penting dalam komunitas internasional.

FDI juga terbukti meningkatkan pertumbuhan ekonomi, menggerakkan ekonomi, juga meningkatkan PDB. FDI dengan efek spillover nya sangat menguntungkan pelaku ekonomi dosmestik dengan teknologi yang dibawa MNE, sehingga dapat menggunakan tekonologi terbaru. Selainh itu juga spillover manajemen mengenai bagaimana mengorganisir bisnis yang lebih efisien dan efektif, sehingga meningkatkan produktivitas. FDI juga menyediakan akses terhadap pasar global kepada pelaku ekonomi domestik, yang mengunutngkan dari segi kuantitatif dan kualitatif. Kuantitatif yaitu meningkatkan penjualan dan eksopor pelaku ekonomi domestik. Sedangkan kualitatif adalah bagaimana penjualan ke pasar global memaksa produsen untuk membuat produk yang lebih baik demi bersaing secara global.

Masuknya FDI juga memiliki imbas terhadap faktor makro ekonomi lainnya. FDI meningkatkan aktivitas ekspor yang membuat kesimbangan neraca perdagangan dan nilai tukar mata uang. FDI juga menyerap tenaga kerja, sehingga menurunkan tingkat pengangguran, memperkuat daya beli, dengan memberikan penghasilan terhadap pegawainya. Serta FDI meyebabkan multiplier effect melalui peningkatan daya beli tersebut, ataupun peningkatan penjualan supplier akibat peningkatan permintaan bahan baku.

Sehingga secara keseluruhan, masuknya FDI menguntungkan ekonomi sebuah negara secara langsung maupun tidak langsung, mendukung kemajuan teknologi, serta menunjang pertumbuhan ekonomi lokasi tujuan investasi.

Mengenai implikasinya terhadap perpajakan, FDI memiliki implikasi positif langsung maupun tidak langsung. Efek positif langsungnya ialah dengan masuknya FDI, otomastis meningkatkan jumlah WP badan (MNE) serta WP orang pribadi (pekerja yang terserap oleh masuknya FDI). Sehingga terdapat potensi PPh yang bertambah dan dapat dikonversi menjadi penerimaan negara. 


\section{JURNALKU}

Volume 1 No. 2, Juni 2021

Efek tidak langsung dari masuknya FDI, yaitu: (1) memperkuat daya beli, sehingga konsumsi juga meningkat, yang menyebabkan peningkatan penerimaan pajak dari PPN; (2) meningkatkan return MNE akibat insentif yang diberikan pemerintah untuk MNE yang melakukan FDI, sehingga terdapat kemampuan keuangan yang lebih untuk melakukan investasi kembali atau ekspansi bisnis; (3) memperbaiki dan membangun infrastruktur yang memudahkan bisnis melakukan pergerakan barang dan jasa, yang meningkatkan penghasilan bisnis; dan (4) meningkatkan ekspor sehingga penerimaan perpajakan dari perdagangan internasional meningkat.

Topik ini akan menjadi lebih lengkap dan menarik apabila dapat diketahui berapa persen penerimaan pajak yang dihasilkan dari setiap dolar FDI masuk, seperti yang dilakukan Okey (2013) terhadap FDI masuk ke Afrika Barat dengan mengkombinasi model ekonometrik dari Heller (1975), Ghura (1998), Mahdavi (2008), dan Danielova dan Sarkar (2012). Namun akibat keterbatasan data dan waktu, penelitian lebih lanjut diperlkukan untuk mendapatkan hasil perhitungan ekonometrik tersebut.

\section{Saran}

ASEAN menuju ekonomi global yang semakin kompetitif ke depannya, harus berkomitmen penuh dalam mendorong agenda integrasinya. Mulai dari memenuhi janji bersama yang dituangkan pada AEC Blueprint 2025. Para aktor politik ASEAN harus mengevaluasi AEC Blueprint 2025, mengevualuasi pelaksaannya, serta merumuskan lebih lanjut dan mendalam langkah-langkah strategis yang harus mulai dilakukan secara bertahap. Selain itu juga para aktor politik tersebut harus melihat masalah ini in helicopter view, menggeser perhatian agenda politiknya dari domestik ke region ASEAN, sehingga tidak lagi hanya mementingkan kepentingan domestik masing-masing negara, namun kepentingan ASEAN secara kolektif.

Penulis menyarankan ASEAN, dalam mengenjot agenda integrasi regionalnya, serta agenda ASEAN yang lain, untuk membentuk badan supranasional yang berfungsi sebagai mekanisme penegakan atas komitmen-komitmen - yang merupakan manifestasi atas agenda integrasi - yang dibuat para negara anggota. Badan ini bertugas untuk memastikan setiap negara yang menjadi signatory dan telah meratifikasi komitmen yang dibuat, menjalankan komitmen tersebut dengan parameter yang jelas. Kemudian badan itu berwenang untuk menentukan jika sebuah anggota tidak melaksanakan komitmen sebagaimana yang telah disetujui, dan memberikan sanksi atas tindakan yang tidak sesuai dengan komitmen.

Para pembuat kebijakan di Indonesia dalam mendesain kebijakan investasi, seharusnya tidak hanya menimbang efek kuantitatif - mengenai berapa banyak dana dan aset yang ditempatkan di Indonesia - tetapi juga efek kualitatif - bagaimana implikasinya terhadap penerimaan pajak - sehingga dengan masuknya FDI, efek yang dihasilkannya akan optimal, mendorong sendi-sendi perekonomian seperti yang diharapkan.

\section{DAFTAR PUSTAKA}

Alguacil, T., Cuadros, \& Orts. (2002). "Foreign Direct Investment, Export, and Domestic Performance in Mexico: A Casuality Analysis". Economic Letters, 77(3), 371-376.

Anh, N. T., \& Cieślik, A. (2015). "Determinants of Foreign Direct Investment from OECD to ASEAN".

Arfa, I. J., Aliasuddin, \& Nasir, M. (2015). "Pengaruh Perdagangan dan Penanaman Modal Asing Terhadap Pertumbuhan Ekonomi di Indonesia: Sebuah Aplikasi Model ARDL". Jurnal Ilmu Ekonomi, 3(3), 1-10.

Atoyebi, K. O., Adekounjo, F. O., Olufemi, E., \& Kadiri, K. O. (2012). "Foreign Trade and Economic Growth in Nigeria: An Empirical Analysis". Journal of Human and Sociology Science, 2(1), 73-80. 


\section{JURNALKU}

Volume 1 No. 2, Juni 2021

Balıkçığlu, E., Dalgıc, B., \& Fazlığlu, B. (2016). "Does Foreign Capital Increase Tax Revenue: The Turkish Case". International Journal of Economics and Financial Issues, 6(2), 776-781. Diunduh dari http://dergipark.gov.tr/download/article-file/363434

Brenton, P., Di Mauro, F., \& Lücke, M. (1999). "Economic Integration and FDI: An Empirical Analysis of Foreign Investment in the EU and in Central and Eastern Europe". Empirica, 95-121.

Chakrabarti, A. (2001). "The Determinants of Foreign Direct Investments: Sensitivity Analyses of Cross-Country Regressions.

Chen, C. (2015). "Determinants and Motives of Outward Foreign Direct Investment from China's Provincial Firms". Transnational Corporations, 23. doi:http://dx.doi.org/10.18356/6ba5ab37-en

Danielova, A., \& Sarkar, S. (2012). "The Effect of Leverage on The Tax-Cut Versus Investment Subsidy Argument". Review of Financial Economics, 20(4), 123-129.

Denielova, A., \& Sarkar, S. (2012). "The Effect of Leverage on Tax-cut Versus Investment Subsidy Argument". Review of Financial Economics, 20(4), 123-129.

Edwards, S. (1990). "Capital Flows, Foreign Direct Investment, and Dept - Equity Swaps in Developing Countries". Working Paper No. 3497.

Effendi, N., \& Soemantri, F. M. (n.d.). "Foreign Direct Investment and Regional Economics Growth in Indonesia: A Panel Data Study". Working Papers in Economics and Development Studies .

Fahnbulleh, M., \& Te Velde, D. W. (2003). "Investment-related Provisions in Regional Trade Agreements". Diunduh dari https://www.odi.org/projects/1484-regional-integrationand-poverty

Ghura, D. (1998). "Tax Revenue in Sub-Saharan Africa: Effects of Economic Policies and Corruption". International Monetary Fund Working Paper No.98/135.

Heller, P. S. (1975). "A Model of Public Finance Behavior in Developing Countries: Aid, Investment, and Taxation". American Economic Review, 65(3), 429-445.

Irawan, F. (2013,). "The Effectiveness of Tax Incentives on Foreign Direct Investment in ASEAN Countries". Jurnal Ilmiah Akuntansi, 1(1), 1-14.

Ismail, N. W., Smith, P., \& Kugler, M. (2009, September). "The Effect of ASEAN Economic Integration on Foreign Direct Investment". Journal of Economic Integration, 24(3), $385-407$.

Jordaan, J. C. (2004). "Foreign Direct Investment and Neighbouring Influences".

Klemm, A., \& Parys, S. V. (2011). "Emperical Evidence of the Effects of the Tax Incentives". IMF Working Paper.

Loree, D., \& Guisinger, S. E. (1995). "Policy and Non-Policy Determinants of U.S. Equity Foreign Direct Investment". Journal of International Business Studies, 281-300.

Mahdavi, S. (2008). "The Level and Composotion of Tax Revenue in Developing Countries: Evidence from Unbalanced Panel Data". International Review of Economics and Finance, 17(4), 607-617.

Moravcsik, A. (1993). "Preferences and Power in the European Community: A Liberal Intergovernmental Approach". Journal of Common Market Studies, 31, 473-523.

Mukhtar, A., Ahmad, M., Waheed, M., Ullah, R. K., \& Inam, H. (2014). "Determinants of Foreign Direct Investment Flow in Developing Countries". International Journal of Academic Research in Applied Science, 26-36.

Nicolini, R., \& Artige, L. (2005). "Evidence on the Determinants of Foreign Direct Investment: The Case of Three European Regions". Diunduh dari http://pareto.uab.es/wp/2005/65505.pdfAsiedu 


\section{JURNALKU}

Volume 1 No. 2, Juni 2021

ODI. (1997). "Foreign Direct Investment Flows to Low-Income Countries: A Review of the Evidence". Retrieved from https://www.odi.org/sites/odi.org.uk/files/odiassets/publications-opinion-files/2626.pdf

OECD. (2008). OECD Benchmark Definition of Foreign Direct Investment. OECD.

Okey, M. K. (2013). "Tax Revenue Effect of Foreign Direct Investment in West Africa". African Journal of Economic and Sustainable Development, 2(1).

Panayotou, T. (2000). "Globalization and Environment". Environment and Development Paper No.1.

Protsenko, A. (2003). "Vertical and Horizontal Foreign Direct Investment in Transition Countries".

Riyadi, D. S. (1998). "Pernanan Arus Masuk Investasi Asing Langsung (FDI) Inflows terhadap Pertumbuhan Ekonomi Indonesia".

Saputra, I. G., \& Kesumajaya, I. W. (2016). "Pengaruh Utang Luar Negeri, Ekspor dan Impor Terhadap Pertumbuhan Ekonomi Indonesia Periode 1996- 2013". Jurnal Ekonomi Pembangunan, 5(4), 385-412.

Scaperlanda, A. E., \& Mauer, L. J. (1969). "The Determinants of U.S. Direct Investment in the EEC". American Economi Review, 59, 558-568.

Schneider, F., \& Frey, B. (1985). "Economic and Political Determinants of Foreign Direct Investment". World Development.

Tay, S., \& Tijaja, J. P. (2017, Agustus). "Implications for the ASEAN Economic Community". Global Megatrends, 13.

Tranholm-Mikkelsen, J. (1991). "Neo-functionalism: Obstinate or Obsolete? A Reappraisal in the Light of the New Dynamism of the EC". Millennium-Journal of International Studies, 1-22.

ASEAN Secretariat. (2017). ASEAN Statistical Year Book 2016/2017. Jakarta: ASEAN Secretariat.

ASEAN Secretariat. (2020). ASEAN Statistical Year Book 2019. Jakarta: ASEAN Secretariat.

BKPM. (2016). Perkembangan Realisasi PMA Menurut Sektor. Jakarta: BKPM.

PricewaterhouseCooper. (2016). Indonesian Infrastructure: Stable Foundations for Growth. Jakarta: PricewaterhouseCooper.

UNCTAD. (1996). World Investment Report. Jenewa: UNCTAD.

Haas, E. (1958). The Uniting of Europe: Political, Social, and Economic Forces. Notre Dame: University of Notre Dame.

Hass, E. (1964). Beyond the Nation State. Stanford: Stanford University Press.

Lindberg, L. N. (1963). The Political Dynamics of European Economic Integration. Stanford: Stanford University Press.

Lindberg, L. N., \& Schneingold, S. A. (1971). Regional Integration: Theory and Research. Cambridge: Harvard University Press. 